\title{
Photocatalytic activity of Fe-doped diopside
}

\author{
YANG He ${ }^{1}$, YANG Ze-jian ${ }^{1}$, HAN Chong ${ }^{2}$, LI Qiang ${ }^{1}$, XUE Xiang-xin ${ }^{1}$ \\ 1. School of Materials and Metallurgy, Northeastern University, Shenyang 110819, China; \\ 2. Research Center for Eco-environmental Sciences, Chinese Academy of Sciences, Beijing 100085, China
}

Received 28 June 2012; accepted 19 November 2012

\begin{abstract}
UV-visible light induced photocatalytic degradation of methylene blue (MB) over Fe-doped diopside was investigated. The structure, composition, morphology and absorption property of UV-visible light of as-prepared samples were characterized using XRD, SEM, FTIR and UV-vis DRS. The experimental results show that doping $\mathrm{Fe}^{3+}$ induced the formation of some new species in diopside, and promoted light adsorption property of diopside in UV-visible region. Photochemical reactivity of Fe-doped diopside obviously depended on the content of doping $\mathrm{Fe}^{3+}$. The diopside with $1.848 \% \mathrm{Fe}^{3+}$ exhibited the superior photocatalytic activity with $95 \%$ degradation of MB under UV-visible light for $3 \mathrm{~h}$. The photocatalytic degradation kinetics of MB over all samples showed the first-order reaction nature.
\end{abstract}

Key words: diopside; methylene blue; $\mathrm{Fe}^{3+}$; photocatalysis; photocatalytic activity; kinetics; first-order reaction

\section{Introduction}

Semiconductor-based photocatalysis has attracted great interest in water splitting and degradation of organic pollutants in air or water since electrochemical photolysis of water over $\mathrm{TiO}_{2}$ electrode was first reported in 1972 [1]. Nowadays, $\mathrm{TiO}_{2}$-based materials have become the most popular ones because of their chemical stability, high photocatalytic reactivity, and nontoxicity [2-9]. Due to its relatively wide band gap energy (3.2 V), however, $\mathrm{TiO}_{2}$ is active only in the $\mathrm{UV}$ region which is less than $5 \%$ of the solar beams on the earth, thus giving rise to very low efficiency. Therefore, great efforts have been performed to extend its adsorption and conversion properties into visible range of the solar spectrum. Numerous methods have been adopted to modify the photocatalyst, such as doping of metal or non-metal elements, surface modification, and coupling with other semiconductors. Recently, The photocatalytic reactivities some photocatalysts with different compositions and structures, including $\mathrm{SrTiO}_{3}, \mathrm{Bi}_{2} \mathrm{GaTaO}_{7}, \mathrm{Bi}_{2} \mathrm{SbVO}_{7}$, $\mathrm{Bi}_{2} \mathrm{WO}_{6}, \mathrm{Bi}_{2} \mathrm{~W}_{2} \mathrm{O}_{9}, \mathrm{Na}_{2} \mathrm{~W}_{4} \mathrm{O}_{13}, \mathrm{ZnWO}_{4}$, and $\mathrm{AgInW}_{2} \mathrm{O}_{8}$, were also studied [10-16]. However, all of these photocatalysts were synthesized under harsh conditions in the laboratory, resulting in inconvenience in practical applications.

Titanium-bearing blast furnace slag (TBFS) has a yield of $4 \times 10^{6} \mathrm{t}$ per year in the process of smelting iron in China. This not only results in waste of resources but also damages the environment. In the past years, XUE et al [17] have demonstrated that TBFS can take the place of $\mathrm{TiO}_{2}$ as the photocatalyst. TBFS exhibited high photocatalytic activity on the degradation of organic pollutants such as $o$-nitrophenol, methyl orange, and nitrobenzene [18-21], and also has superiority in dealing with wastewater containing inorganic heavy metal, such as $\mathrm{Cr}^{6+}$ [22]. However, it is still an open question that how TBFS takes part in photocatalytic reaction. Though the photocatalytic activity of $\mathrm{CaTiO}_{3}$ as one of the main species in TBFS has been reported $[23,24]$, another main species (diopside) accounting for $9 \%-15 \%$ of TBFS has not been investigated. In the process of smelting iron, $\mathrm{Fe}^{3+}$ may penetrate into lattice of diopside, thus modifying its photocatalytic activity. In this work, therefore, Fe-doped diopside was characterized using XRD, SEM, FTIR and UV-vis DRS. Its photocatalytic activity was also investigated by measuring the photo-degradation of methylene blue (MB) under UV-visible light. This will help to understand the nature of photocatalytic activity of TBFS as overall photocatalyst. 


\section{Experimental}

\subsection{Production of Fe-doped diopside}

The diopside was synthesized by a solid-state method. $\mathrm{CaCO}_{3}, \mathrm{MgO}$ and $\mathrm{SiO}_{2}$ (AR, Sinopharm Chemical Reagent Lo., Ltd) were used as starting materials.

$$
\mathrm{CaCO}_{3}+\mathrm{MgO}+2 \mathrm{SiO}_{2}=\mathrm{MgO} \cdot \mathrm{CaO} \cdot 2 \mathrm{SiO}_{2}+\mathrm{CO}_{2}
$$

Calcination was performed at $1400{ }^{\circ} \mathrm{C}$ for $3 \mathrm{~h}$ in an electric furnace $\left(6 \mathrm{X}_{2}-8-10\right.$, Sheyang Changcheng Industrial Furnace Factory, China). To obtain Fe-doped diopside, a solution of ferric nitrate in ethanol $(0.05$ $\mathrm{mol} / \mathrm{L}$ ) was added into ethanol suspension solution of pure diopside. The amounts of the added $\mathrm{Fe}^{3+}$ accounting for the total mass of $\mathrm{CaTiO}_{3}$ were $0.462 \%, 0.924 \%$, $1.848 \%, 2.772 \%$, and $3.696 \%$, respectively. The precursor solution was then stirred for $1 \mathrm{~h}$ to evaporate most of the ethanol. After that, mixed powders were moved into the electric furnace and calcined at $500{ }^{\circ} \mathrm{C}$ for $2 \mathrm{~h}$. Finally, the prepared solids were ground into fine powders prior to characterization and photocatalytic property examination.

\subsection{Characterization}

The crystal structures of pure and Fe-doped diopside were analyzed at room temperature using X-ray diffractometer (XRD, DX-2600) with $\mathrm{Cu} \mathrm{K}_{\alpha}$ radiation under $40 \mathrm{kV}$ and $300 \mathrm{~mA}$. The scanned range was $2 \theta=$ $20^{\circ}-75^{\circ}$ with a step of $2 \theta=0.02^{\circ}$ and $1 \mathrm{~s} / \mathrm{step}$. The morphology and particle size were investigated with scanning electron microscope (SEM, S-3400N). The chemical compositions were examined by the Fourier transform infrared spectra (FT-IR, Thermo Nicolet-380) in the range of $4000-400 \mathrm{~cm}^{-1}$ with $\mathrm{KBr}$ as a reference. The UV-visible diffuse reflectance was measured using a $\mathrm{UV}$-visible spectrophotometer (UV-2550) in the range of 250-800 nm.

\subsection{Photocatalytic activity test}

The degradation rate of $\mathrm{MB}$ in an aqueous solution under UV-visible light irradiation was measured to investigate the photocatalytic activities of pure and Fe-doped diopside. A total of $0.3 \mathrm{~g}$ of the prepared sample was dispersed in $200 \mathrm{~mL}$ of $5 \mathrm{mg} / \mathrm{L} \mathrm{MB}$ aqueous solution in quartz vessel. Before irradiation, the aqueous suspension was magnetically stirred for $5 \mathrm{~h}$ in the dark to reach an adsorption/desorption equilibrium of $\mathrm{MB}$ on the sample surface. Subsequently, the photocatalytic reactivity tests were carried out under aerobic conditions. A $500 \mathrm{~W} \mathrm{Hg}$ lamp with $365 \mathrm{~nm}$ dominant wavelength, extended into the MB solution, was employed as the UV-visible light source. During the photocatalytic reaction, the reaction temperature was kept at room temperature by using circular cooling water. At the different intervals, $5 \mathrm{~mL}$ of suspension solution was sampled and subsequently centrifuged at a rate of 3000 $\mathrm{r} / \mathrm{min}$ for $10 \mathrm{~min}$ to remove the suspended particles. The concentration changes of MB were then monitored by measuring the absorbance of the solution at $664 \mathrm{~nm}$ (the maximum absorption wavelength for MB) using a UV-2550 spectrophotometer. The photo-degradation rate $(X)$ of $\mathrm{MB}$ was determined by the following equation:

$X=c_{t} / c_{0}$

where $c_{0}$ is the initial concentration of $\mathrm{MB}$ and $c_{t}$ is the concentration at time $t$.

\section{Results and discussion}

\subsection{Photocatalyst characterization}

The crystalline structures of pure and Fe-doped diopside with different contents of $\mathrm{Fe}^{3+}$ were identified by XRD. As shown in Fig. 1, compared with that of pure diopside, XRD pattern of Fe-doped diopside remained unchanged in the range of $20^{\circ}-37^{\circ}$, while exhibited significant change in the range of $37^{\circ}-70^{\circ}$. The intensities of peaks at $38.50^{\circ}, 42.45^{\circ}, 44.60^{\circ}, 49.95^{\circ}$, $52.40^{\circ}, 56.75^{\circ}$, and $65.95^{\circ}$, obviously decreased. Some new peaks appeared at $41.15^{\circ}, 54.35^{\circ}, 58.80^{\circ}, 60.95^{\circ}$, and $64.85^{\circ}$. These results suggest that $\mathrm{Fe}^{3+}$ induced the formation of some new species, which may be iron-containing solid solution $\left(\mathrm{Ca}_{1.022} \mathrm{Fe}_{0.194} \mathrm{Mg}_{0.906} \mathrm{O}_{6} \mathrm{Si}_{1.9}\right.$, $\mathrm{Ca}_{1.007} \mathrm{Fe}_{0.455} \mathrm{Mg}_{0.805} \mathrm{O}_{6} \mathrm{Si}_{1.75}$, and $\left.\mathrm{CaFe}_{0.18} \mathrm{Mg}_{0.82} \mathrm{O}_{6} \mathrm{Si}_{2}\right)$ according to the JCPDS database.

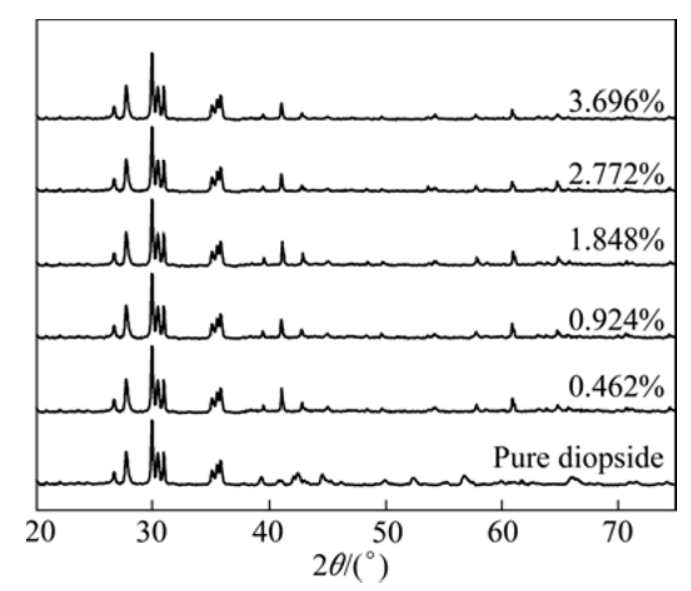

Fig. 1 XRD patterns of diopside samples with different contents of $\mathrm{Fe}^{3+}$

Figure 2 shows the typical SEM images of pure and diopside samples with different contents of $\mathrm{Fe}^{3+}$. As shown in Fig. 2, there was no obvious difference in morphologies among these samples which exhibited irregular polygons shape. It has been reported that a 


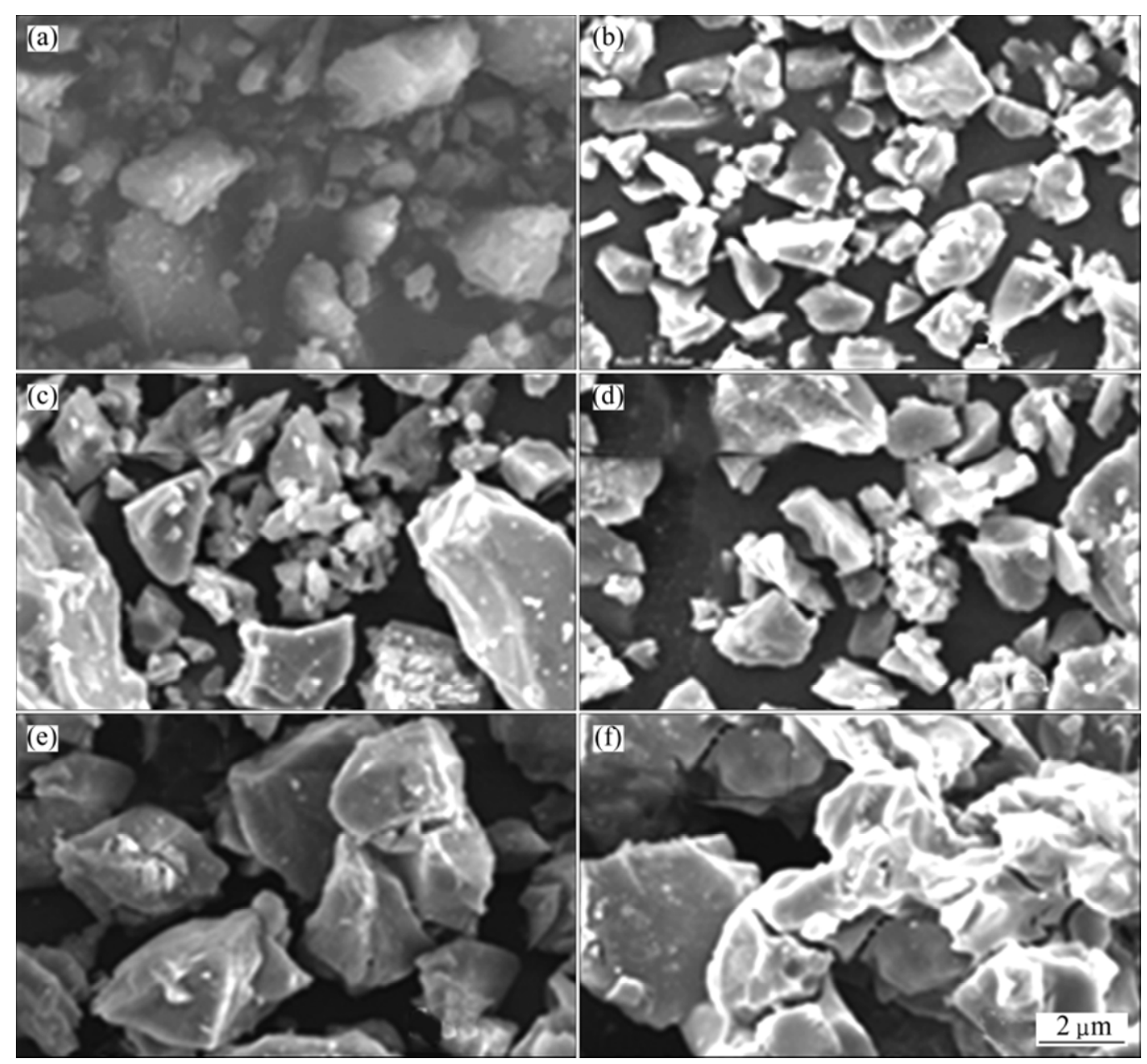

Fig. 2 SEM images of diopside samples with different contents of $\mathrm{Fe}^{3+}$ : (a) Pure diopside; (b) With $0.462 \% \mathrm{Fe}^{3+}$; (c) With $0.924 \%$ $\mathrm{Fe}^{3+}$; (d) With $1.848 \% \mathrm{Fe}^{3+}$; (e) With $2.772 \% \mathrm{Fe}^{3+}$; (f) With $3.696 \% \mathrm{Fe}^{3+}$

rough surface may provide more active sites for photocatalysis [25]. Thus, little difference in micromorphological surface should not be responsible for their different photocatalytic activities. Additionally, it should be noticed that particles showed a certain degree of sintering with increasing content of $\mathrm{Fe}^{3+}$, thus agglomerating into larger ones.

Figure 3 summarizes the FRIR spectra of the pure and Fe-doped diopside. The broad band at $3440 \mathrm{~cm}^{-1}$ was related to superposition of the vibration bands of hydroxyl groups and the stretching vibrations of adsorbed water molecules, while the peak located at $1630 \mathrm{~cm}^{-1}$ can be ascribed to bending vibrations of group $\mathrm{O}-\mathrm{H}$ [26]. Peaks at 1110 and $950 \mathrm{~cm}^{-1}$ can be assigned to the stretching vibrations of $\mathrm{Si}-\mathrm{O}-\mathrm{Si}$ and $\mathrm{Si}-\mathrm{O}-\mathrm{M}$ $(\mathrm{Mg}, \mathrm{Fe})$ [27]. Adsorption at $530 \mathrm{~cm}^{-1}$ corresponded to the $\mathrm{Fe}-\mathrm{O}-\mathrm{Si}$ bridging stretching mode [28]. Compared to the pure diopside, the intensities of peaks at 3440 and $1630 \mathrm{~cm}^{-1}$ of Fe-doped diopside exhibited an increase with increasing content of $\mathrm{Fe}^{3+}$. This indicates that $\mathrm{Fe}^{3+}$ may contribute to the adsorption of the water or

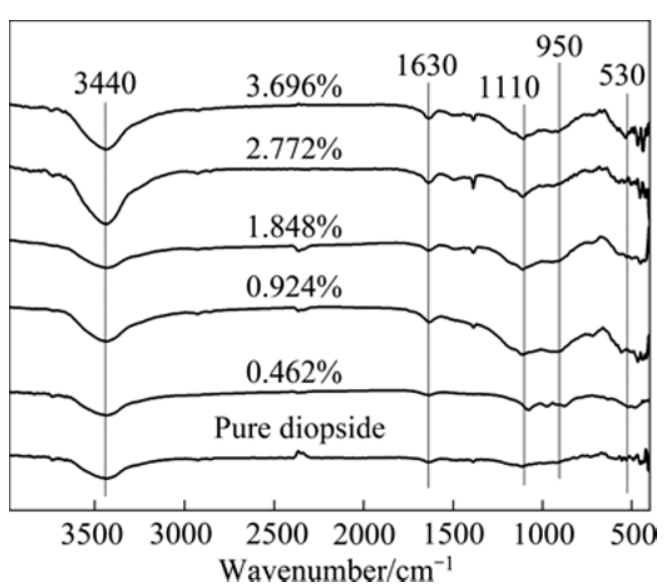

Fig. 3 FTIR spectra of diopside samples with different contents of $\mathrm{Fe}^{3+}$

hydroxyl groups on the diopside surface. Additionally, the intensity of $\mathrm{Fe}-\mathrm{O}-\mathrm{Si}\left(1110\right.$ and $\left.950 \mathrm{~cm}^{-1}\right)$ also increased with increasing content of $\mathrm{Fe}^{3+}$, further determining the introduction of $\mathrm{Fe}^{3+}$ into lattice of diopside and changes of chemical compositions. 
Figure 4 displays the UV-visible diffuse reflectance spectra of pure diopside and diopside samples doped with different content of $\mathrm{Fe}^{3+}$. As shown in Fig. 4, with increasing contents of $\mathrm{Fe}^{3+}$, Fe-doped diopsides exhibited significantly enhanced light adsorption property in the UV-visible region compared with pure diopside. According to the FTIR spectra, the introduction of Fe into diopside induced the formation of $\mathrm{Fe}-\mathrm{O}-\mathrm{Si}$, thus producing impurity energy level between the conduction band and the valence band. Therefore, the enhanced adsorption in the UV-visible region should be ascribed to the electron excitation from the isolated energy level to the conduction band of diopside. However, the light adsorption property of diopside exhibited a certain decrease when the content of $\mathrm{Fe}^{3+}$ was more than $2.772 \%$. In SEM images, it was observed that the Fe-doped diopside samples with higher content of $\mathrm{Fe}^{3+}$ easily agglomerated into larger ones. This may lead to covering some active sites of absorbing UV-visible light and thus decreasing light adsorption property of Fe-doped diopside.

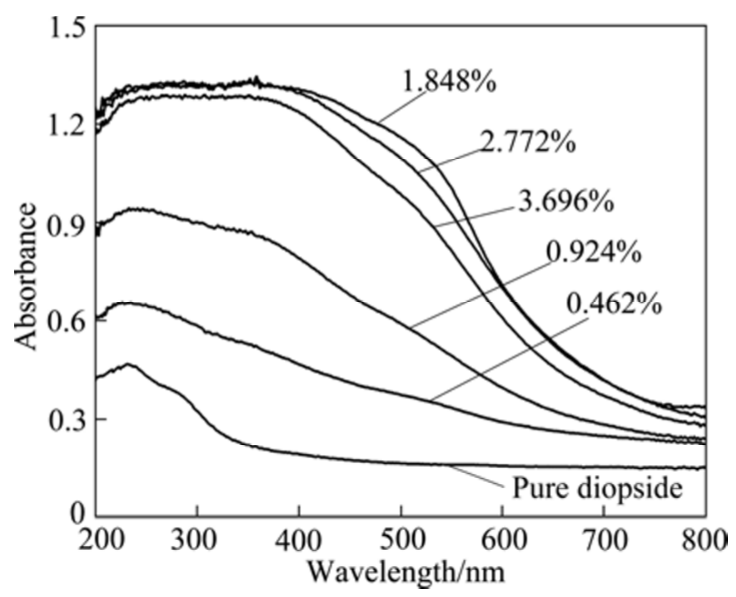

Fig. 4 UV-visible spectra of diopside with different contents of $\mathrm{Fe}^{3+}$

\subsection{Photocatalytic performance}

Prior to UV-visible light irradiation, the absorption of $\mathrm{MB}$ on the pure diopside and Fe-doped diopside samples was investigated in the dark. The MB suspension can totally reach an absorption/desorption equilibrium within $30 \mathrm{~min}$. Based on the absorption experiment, about $31 \%$ of $\mathrm{MB}$ was adsorbed on the photocatalyst sample. It should be pointed out that the direct irradiation without catalyst caused only about decomposition of $10 \%$ of MB solution within $3 \mathrm{~h}$, which can be ascribed to the photosensitized ability of $\mathrm{MB}$ molecules. Figure 5(a) depicts the UV-visible lightinduced photocatalytic degradation of MB over various samples. The degradation rate of MB by pure diopside was $28 \%$ after irradiation for $3 \mathrm{~h}$, demonstrating that pure diopside has a certain photocatalytic activity. For degradation of $\mathrm{MB}$, all Fe-doped diopside samples showed higher photocatalytic activity than pure diopside. The diopside with $1.848 \% \mathrm{Fe}^{3+}$ exhibited superior photocatalytic activity with $95 \%$ degradation of MB after irradiation for $3 \mathrm{~h}$. This suggests that doping Fe iron has a significantly enhanced influence on the photocatalytic activity of diopside. Meanwhile, it was also found that the photocatalytic activity of Fe-doped diopside greatly depends on the content of $\mathrm{Fe}^{3+}$.
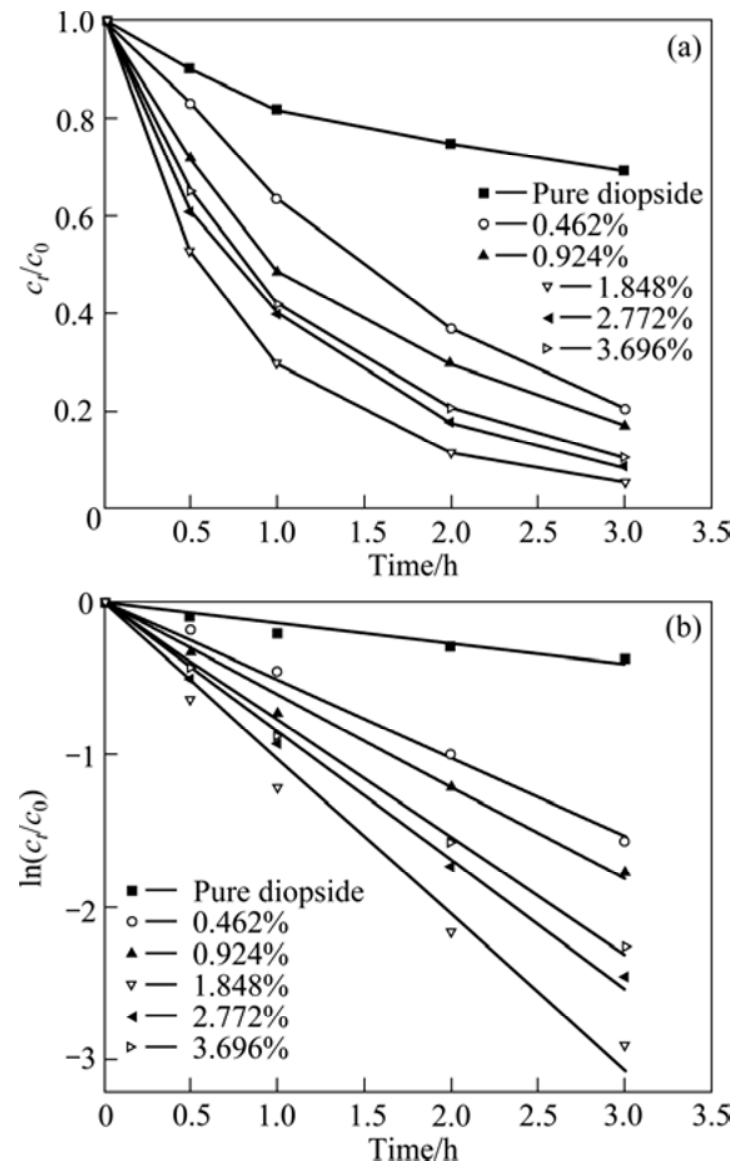

Fig. 5 Photocatalytic decomposition of MB by diopsides with different contents of $\mathrm{Fe}^{3+}$ (a), plot of $\ln \left(c_{t} / c_{0}\right)$ against illumination time $t$ for different samples (b)

To evaluate the effect of $\mathrm{Fe}^{3+}$ on the photocatalytic activity of diopside, the apparent reaction rate constants of MB over diopside was calculated. The heterogeneous photocatalytic degradation reactions generally follow Langmuir-Hinshelwood kinetic mechanism [29,30], as expressed by

$\ln \left(c_{t} / c_{0}\right)=k t+a$

where $c_{t}$ is the concentration at the reaction time $t, c_{0}$ is the initial concentration, and $k$ is the apparent rate constant. Figure 5(b) shows the linear fitting results of decomposition of MB over pure diopside and Fe-doped diopside samples, suggesting that there was a well linear correlation between $\ln \left(c_{t} / c_{0}\right)$ and illumination time. This 
demonstrates that the photocatalytic degradation kinetics of MB over all samples followed the first-order reaction. The rate constants for $\mathrm{MB}$ degradation over pure diopside and Fe-doped diopside samples with $0.462 \%$ $\mathrm{Fe}^{3+}, 0.924 \% \mathrm{Fe}^{3+}, 1.848 \% \mathrm{Fe}^{3+}, 2.772 \% \mathrm{Fe}^{3+}$, and $3.696 \% \mathrm{Fe}^{3+}$, were determined to be $0.14,0.51,0.61,1.0$, 0.84 , and $0.77 \mathrm{~h}^{-1}$, respectively. It is noticed that the diopside with $1.848 \% \mathrm{Fe}^{3+}$ exhibits the highest photocatalytic activity for degradation of MB. As shown in Fig. 4, the diopside with $1.848 \% \mathrm{Fe}^{3+}$ approximately shows the same absorbance as that with $2.772 \%$ or $3.696 \% \mathrm{Fe}^{3+}$ in the UV light region. However, the diopside with $1.848 \% \mathrm{Fe}^{3+}$ exhibits higher photocatalytic activity than that with $2.772 \%$ or $3.696 \% \mathrm{Fe}^{3+}$ (Fig. 5), which can be ascribed to higher absorbance of the diopside with $1.848 \% \mathrm{Fe}^{3+}$ in the visible light region (Fig. 4). This suggests that the Fe-doped diopside should also show photoactivity in the visible light irradiation. Additionally, diopside with $2.772 \%$ or $3.696 \% \mathrm{Fe}^{3+}$ had a larger particle size, leading to the exploration of less active sites and lower photocatalytic activity than the diopside with $1.848 \% \mathrm{Fe}^{3+}$.

\section{Conclusions}

The photocatalytic properties of pure diopside and Fe-doped diopside samples were investigated under UV-visible light illumination. The introduction of $\mathrm{Fe}^{3+}$ into the diopside lattice can cause formation of $\mathrm{Fe}-\mathrm{O}-$ $\mathrm{Si}$, thus enhancing the light absorption property in the UV-visible region. The Fe-doped diopside showed higher photocatalytic activity for the degradation of methylene blue (MB) than pure diopside. The photocatalytic activity of the Fe-doped diopside significantly depended on the content of $\mathrm{Fe}^{3+}$, which contributed to the difference of particle size and light absorbing property. The diopside with $1.848 \% \mathrm{Fe}^{3+}$ exhibited the highest photocatalytic activity with $95 \%$ degradation of $\mathrm{MB}$ under UV-visible light irradiation for $3 \mathrm{~h}$. The kinetics fitting results demonstrate that the degradation kinetics of MB over diopside followed the first-order reaction.

\section{References}

[1] FUJISHIMA A, HONDA K. Electrochemical photolysis of water at a semiconductor electrode [J]. Nature, 1972, 238: 37-38.

[2] GAO Yue-jun, XU Yi-ming. Effect of fluoride doping and adsorption on the photocatalytic activity of $\mathrm{TiO}_{2}[\mathrm{~J}]$. Acta PhysicoChimica Sinica, 2012, 28(3): 641-646. (in Chinese)

[3] JING Ming-jun, WANG Yan, QIAN Jun-jie, ZHANG Mei, YANG Jian-jun. Preparation of Pt-doped $\mathrm{TiO}_{2}$ by hydrothermal method and its photocatalytic performance under visible light irradiation [J]. Chinese Journal of Catalysis, 2012, 33(3): 550-556. (in Chinese)

[4] WENG Jing-zheng, CHEN Shao-ping, WU Zong-hua. Photocatalytic degradation of aqueous nonylphenol ethoxylate-10 by titanium dioxide composite sheets [J]. Acta Scientiae Circumstantiae, 2010,
30(6): 1204-1210. (in Chinese)

[5] ZHANG Z, WANG X, LONG J, GU Q, DING Z, FU X. Nitrogen-doped titanium dioxide visible light photocatalyst: Spectroscopic identification of photoactive centers [J]. Journal of Catalysis, 2010, 276: 201-214.

[6] YU C, YU J C, ZHOU W, YANG K. $\mathrm{WO}_{3}$ Coupled P-TiO photocatalysts with mesoporous structure [J]. Catalysis Letters, 2010, 140: 172-183.

[7] LI H, ZHANG X, HUO Y, ZHU J. Supercritical preparation of a highly active S-doped $\mathrm{TiO}_{2}$ photocatalyst for methylene blue mineralization [J]. Environmental Science Technology, 2007, 41, 4410-4414.

[8] LIU Y, CHEN G, ZHOU C, HU Y, FU D, LIU J, WANG Q. Higher visible photocatalytic activities of nitrogen doped $\mathrm{In}_{2} \mathrm{TiO}_{5}$ sensitized by carbon nitride [J]. Journal of Hazardous Materials, 2011, 190, 75-80.

[9] XU J, LI J, DAI W, CAO Y, LI H, FAN K. Simple fabrication of twist-like helix N, S-codoped titania photocatalyst with visible-light response [J]. Applied Catalysis B, 2008, 79: 72-80.

[10] XIE T, SUN X, LIN J. Enhanced photocatalytic degradation of RhB driven by visible light-induced MMCT of Ti(IV)-O-Fe(II) formed in Fe-doped $\mathrm{SrTiO}_{3}[\mathrm{~J}]$. The Journal of Physical Chemistry C, 2008, 112: 9753-9759.

[11] LUAN J, PAN B, PAZ Y, LI Y, WU X, ZOU Z. Structural, photophysical and photocatalytic properties of new $\mathrm{Bi}_{2} \mathrm{SbVO}_{7}$ under visible light irradiation [J]. Physical Chemistry Chemical Physics, 2009, 11: 6289-6298.

[12] XU C, WEI X, GUO Y, WU H, REN Z, XU G, SHEN G, HAN G. Surfactant-free synthesis of $\mathrm{Bi}_{2} \mathrm{WO}_{6}$ multilayered disks with visible-light-induced photocatalytic activity [J]. Materials Research Bulletin, 2009, 44: 1635-1641.

[13] YE D, LI D, ZHANG W, SUN M, HU Y, ZHANG Y, FU X. A new photocatalyst $\mathrm{CdWO}_{4}$ prepared with a hydrothermal method [J]. The Journal of Physical Chemistry C, 2008, 112: 17351-17356.

[14] TANG J, ZOU Z, YE J. Photophysical and photocatalytic properties of $\mathrm{AgInW}_{2} \mathrm{O}_{8}[\mathrm{~J}]$. The Journal of Physical Chemistry B, 2003, 107: $14265-14269$.

[15] LIN J, LIN J, ZHU Y. Controlled synthesis of the $\mathrm{ZnWO}_{4}$ nanostructure and effects on the photocatalytic performance [J]. Inorganic Chemistry, 2007, 46(20): 8372-8378.

[16] TANG J, ZOU Z, YE J. Photocatalytic decomposition of organic contaminants by $\mathrm{Bi}_{2} \mathrm{WO}_{6}$ under visible light irradiation $[\mathrm{J}]$. Catalysis Letters, 2004, 92: 53-56.

[17] XUE Xiang-xin, LEI Xue-fei, YANG He, DUAN Pei-ning. Photocatalytic reduction of $\mathrm{Cr}(\mathrm{VI})$ by sulfate modified titanium-bearing blast furnace slag [J]. Journal of Northeastern University: Natural Science, 2009, 30(2): 217-220. (in Chinese)

[18] YANG He, XUE Xiang-xin, DONG Xue-wen. Anti-staphylococcus aureus properties of titanium-bearing furnace slag [J]. Journal of the Chinese Ceramic Society, 2008, 36(3): 387-390. (in Chinese)

[19] ZHAO Na, YANG He, XUE Xiang-xin, LIU Mao, TIAN Hai-chuang, DONG Xue-wen. Experimental study on degradation of ortho-nitrophenol with high-titanium slag as photocatalytic materials [J]. Journal of the Chinese Ceramic Society, 2005, 33(2): 202-205. (in Chinese)

[20] WANG Yu-zheng, XUE Xiang-xin, LEI Xue-fei. Investigation on photocatalytic activity of $\mathrm{S}$ doped titania-bearing blast furnace slag [J]. Journal of Materials and Metallurgy, 2009, 8(1): 73-76. (in Chinese)

[21] XUE Xiang-xin, KANG Yan-hong, YANG He, LI Wei, KANG Ze-shuang. Degradation of nitrobenzene by electrochemical catalysis with titania-containing slags $[\mathrm{J}]$. The Chinese Journal of Process Engineering, 2008, 8(5): 1138-1142. (in Chinese)

[22] LEI Xue-fei, XUE Xiang-xin, YANG He. Effect of surface 
modification on photocatalytic effect of titanium-bearing blast furnace slag [J]. Journal of Northeastern University: Natural Science, 2010, 31(6): 839-842. (in Chinese)

[23] HAN Chong, YANG He, XUE Xiang-xin. Photocatalytic property of the solid-phase synthesized titanate calcium [J]. Environmental Chemistry, 2010, 29(5): 832-835. (in Chinese)

[24] YANG He, HAN Chong, XUE Xiang-xin. Effect of baking temperature on photocatalytic properties of calcium titanate [J]. Journal of Northeastern University: Natural Science, 2010, 31(9): 1297-1299. (in Chinese)

[25] WANG D, YE J, KAKO T, KIMURA T. Photophysical and photocatalytic properties of $\mathrm{SrTiO}_{3}$ doped with $\mathrm{Cr}$ cations on different sites [J]. The Journal of Physical Chemistry B, 2006, 110: $15824-15830$.

[26] KO H Y Y, MIZUHATA M, KAJINAMI A, DEKI S. Fabrication of high performance thin films from metal fluorocomplex aqueous solution by the liquid phase deposition [J]. J Fluorine Chem, 2003,
120: $157-163$.

[27] KARAKASSIDES M A, GOURNIS D, PETRIDIS D. An infrared reflectance study of $\mathrm{Si}-\mathrm{O}$ vibrations in thermally treated alkali-saturated montmorillonites [J]. Clay Mineral, 1999, 34: 429-438.

[28] MA M, ZHANG Y, YU W, SHEN H, ZHANG H, GU N. Preparation and characterization of magnetite nanoparticles coated by amino silane [J]. Colloids and Surfaces A, 2003, 212: 219-226.

[29] ZHOU J K, LV L, YU J, LI H, GUO P, SUN H, ZHAO X S. Synthesis of self-organized polycrystalline F-doped $\mathrm{TiO}_{2}$ hollow microspheres and their photocatalytic activity under visible light [J]. The Journal of Physical Chemistry, 2008, 112: 5316-5321.

[30] ZHOU X, YANG H, WANG C, MAO X, WANG Y, YANG Y, LIU G. Visible light induced photocatalytic degradation of rhodamine $B$ on one-dimensional iron oxide particles [J]. The Journal of Physical Chemistry C, 2010, 114: 17051-17061.

\section{铁掺杂透辉石的光催化活性}

杨 合 $^{1}$, 杨泽健 ${ }^{1}$, 韩 冲 $^{2}$, 李 强 $^{1}$, 薛向欣 ${ }^{1}$

1. 东北大学 材料与冶金学院, 沈阳 110819 ;

2. 中国科学院 生态环境研究中心, 北京 100085

摘 要: 以亚甲基蓝为光催化降解标的物, 考察了在紫外可见光下掺杂 $\mathrm{Fe}^{3+}$ 的透辉石的光催化活性。应用 XRD、 SEM、FT-IR 和 UV-vis DRS 等方法表征了掺杂 $\mathrm{Fe}^{3+}$ 的透辉石的结构、组成、形貌和紫外可见光吸收能力。实验 结果表明: $\mathrm{Fe}^{3+}$ 的掺入在透辉石内产生了一些含 $\mathrm{Fe}^{3+}$ 的新物种, 提高了透辉石的紫外可见光吸收能力; 透辉石的 光催化活性明显依赖于 $\mathrm{Fe}^{3+}$ 掺入量; 当 $\mathrm{Fe}^{3+}$ 掺杂量为 $1.848 \%$ 时, 透辉石具有最高的光催化活性, 光反应 $3 \mathrm{~h}$ 后, 亚甲基蓝降解率达到 $95 \%$; 动力学模拟可知亚甲基蓝在透辉石上的反应遵循一级反应动力学。

关键词: 透辉石; 亚甲基蓝; $\mathrm{Fe}^{3+}$; 光催化; 光催化活性; 动力学; 一级反应

(Edited by YANG Hua) 